\title{
Drought-tolerant transgenic Swingle Citrumelo controls accumulation of proline modulating the expression of key genes of the proline metabolism
}

\begin{abstract}
Diliane Barichello ${ }^{1}$, Renato Farinacio ${ }^{1}$, Camilla Carvalho Numes dos Santos ${ }^{1}$, Giselly Aparecida Andrade ${ }^{1}$, Getúlio Takashi Nagashima ${ }^{1}$, Deoclécio Domingues Garbúglio ${ }^{1}$, Inês Fumiko Ubukata Yada ${ }^{1}$, Regiane de Fátima Travensolo ${ }^{2}$, Beatriz Cutilak Bianchi ${ }^{2}$, Luiz Gonzaga Esteves Vieira ${ }^{3} \&$ Eduardo Fermino Carlos ${ }^{1}$
\end{abstract}

\begin{abstract}
SUMMARY
The Brazilian citrus industry is primarily not irrigated, and growers often face dry spells that affects tree development, flowering, fruit set and juice quality, limiting the use of rootstocks and imposing considerable yield variation upon the industry. To mitigate water stress, cells increase osmoprotective compounds, such as the amino acid proline. The objectives of this study were to evaluate physiological parameters for transgenic Swingle citrumelo (Citrus paradisi Macfad. cv. Duncan x Poncirus trifoliata L. Raf.) rootstock able to accumulate proline, and to assess gene expression level of key enzymes in the proline biosynthesis and glutamate pathway. The transgenic plants resulted from the integration of the P5CS-F129A gene from Vigna aconitifolia, that codes for the mutant $\Delta 1$-pyrroline-5-carboxylate synthetase (P5CS), under the control of the constitutive CaMV35S promoter. The water deficit experiment was conducted under greenhouse conditions, and transcriptional analysis of leaf tissue using RNA-seq was performed. Transgenic plants had significant higher proline accumulation up to intermediated stress level, and higher Relative Water Content (RWC) and stomatal conductance from 26 up to 34 days without irrigation (d.w.i) compared to non-transgenic control. Analysis of the transcriptional data showed that the expression of the native $\Delta$-pyrroline-5-carboxylate reductase (P5CR) was down-regulated while the expression of the proline dehydrogenase (ProDH) gene increased respectively in transgenic non irrigated and in both transgenic treatmens (irrigated and not irrigated), probably to counter balance proline accumulation under those circunstances. Based on this knowledge, new drought-tolerant transgenic rootstocks can be developed to tolerate drought stress for longer periods of time than drought sensitive genotypes.
\end{abstract}

Index terms: rootstock, drought, GMO, transgenics, citrus, RNA-seq.

\footnotetext{
${ }^{1}$ Instituto Agronômico do Paraná - IAPAR, Londrina, PR, Brazil

2 ParteCurae P\&D - PARTECURAE, São Carlos, SP, Brazil

${ }^{3}$ Universidade do Oeste Paulista - UNOESTE, Presidente Prudente, SP, Brazil

Corresponding author: Eduardo Fermino Carlos, Instituto Agronômico do Paraná - IAPAR, Rod. Celso Garcia Cid, Km 375, CP 481, CEP 86001-970, Londrina, PR, Brazil. E-mail: efcarlos@iapar.br
} 


\section{Citrumelo Swingle transgênico tolerante à seca controla a acumulação de prolina modulando a expressão de genes-chave do metabolismo da prolina}

\section{RESUMO}

A maioria das áres de cítros não Brasil não irrigada, e os produtores frequentemente enfrentam períodos de seca que afetam o desenvolvimento das árvores, a floração, o desenvolvimento das frutas e a qualidade do suco, limitando o uso de porta-enxertos e impondo uma considerável variação de rendimento ao setor. Para mitigar o estresse hídrico, as células aumentam os compostos osmoprotetivos, como do aminoácido prolina. Os objetivos deste estudo foram avaliar os parâmetros fisiológicos para o Swingle citrumelo transgênico (Citrus paradisi Macfad. cv. Duncan x Poncirus trifoliata L. Raf.) capaz de acumular prolina e avaliar o nível de expressão gênica das principais enzimas na biossíntese de prolina e a rota do glutamato. As plantas transgênicas resultaram da integração do gene P5CS-F129A de Vigna aconitifolia, que codifica a $\Delta$ 1-pirrolina-5-carboxilato-sintetase mutante (P5CS), sob o controle do promotor constitutivo CaMV35S. O experimento de déficit hídrico foi conduzido em condições de casa-de-vegetação, e foi realizada análise transcricional do tecido foliar usando RNA-seq. As plantas transgênicas apresentaram acúmulo significativo de prolina até o nível de estresse intermediado, e maior conteúdo de água relativa (RWC) e condutância estomática de 26 até 34 dias sem irrigação (d.s.i) em comparação com o controle não transgênico. A análise dos dados da transcrição mostrou que a expressão da $\Delta$-pirrolina-5-carboxilato redutase nativa (P5CR) foi regulada para baixo enquanto a expressão do gene da proline desidrogenase (ProDH) aumentou, respectivamente, em transgênicos não irrigados e em ambos os tratamentos transgênicos (irrigados e não irrigados), provavelmente para contrabalançar o acúmulo de prolina sob essas circunstâncias. Com base nesse conhecimento, novos porta-enxertos transgênicos tolerantes à seca podem ser desenvolvidos para tolerar o estresse por períodos prolongados do que os genótipos sensíveis à seca.

Termos de indexação: porta-enxertos, seca, transgênicos, cítricos, RNA-seq.

\section{INTRODUCTION}

Rangpur lime (Citrus limonia Osbeck) is the main rootstock in Brazil, mainly because of its drought tolerance, productivity, precocity and general rusticity (Carlos et al., 1997). In Brazil, Swingle citrumelo (Citrus paradise Macfad. x Poncirus trifoliata L. Raf.) is currently the second mostly planted rootstock, and has gained notoriety mainly for its resistance to Sudden Death (Pompeu Junior $\&$ Blumer, 2008). Fruits from orange trees grafted on Swingle have good quality, with adequate levels of sugars and high industrial yield for juice extraction. However, Swingle is not as tolerant to drought as Rangpur, which is an unfavorable characteristic of this genotype for the mostly non irrigated Brazilian citrus industry. Water deficit is often considered the most limiting factor to plant growth and development, and citrus flowering and fruit set are critical periods, dependent on weather conditions, that ultimately determine the following annual production (Albrigo \& Saúco, 2004).

The responses of citrus plants to water deficit start with stomatal closure and consequent reduction in photosynthesis and plant growth, and may cause falling of leaves and young fruits, reduction in yield and overall plant stress (Sentelhas, 2005). These effects are directly related to the duration and severity of the stress (Arruda et al., 2015) and the stage of plant development in which it occurs (Bürling et al., 2013). In a critical level of water supply, depending on the species, photosynthetic activity will cease (Pimentel, 2004) as a result of the stomata closure, which is a form of protection against plant desiccation. However, it causes simultaneously restriction on assimilation of atmospheric carbon dioxide $\left(\mathrm{CO}_{2}\right)$ (Carneiro, 2011), and increases toxic reactive oxygen species (ROS) in plants (Pereira et al., 2012).

The accumulation of osmotically active solutes, as a result of drought stress, is an important mechanism of adjustment adopted by plants that tolerate drought (Chaves Filho \& Stacciarini-Seraphin, 2001). It is considered one of the most effective processes for maintenance of cell turgor, stomatal opening and photosynthesis, even under low water potential in the soil (Kramer \& Boyer, 1995). During drought, higher plants accumulate a variety of solutes such as sugars and alcohols of sugars (mannitol, 
trehalose and galactinol), amino acids (proline), amines (glycinebetaine and polyamines) and ions in the cytosol that help decreasing its osmotic potential (Valliyodan \& Nguyen, 2006), and alter the whole metabolic profile of cells in water stressed plants (Oliveira et al., 2014). Accumulation of free proline helps to maintain the absorption of water and the turgor pressure of the cell, thus contributing to the stability of stomatal opening, photosynthesis and plant growth during environmental variations (Turkan, 2011).

Proline is also reservoir of carbon and nitrogen affecting acidification of the cells (Hare \& Cress, 1997) and playing active role in affinity, folding, stability and transition between the proteins. The proline accumulation represents a general response to stress in plants under drought, high salinity, high temperature, cold, UV radiation and heavy metal conditions (Špoljarević et al., 2011).

In higher plants, proline is synthesized from glutamate and ornithine (Adams \& Frank, 1980), but the major proline biosynthesis pathway in osmotic stress conditions is through glutamate (Delauney et al., 1993). Glutamate is converted to glutamate semialdehyde by the enzyme $\Delta^{1}$-pyrroline-5-carboxylate synthetase (P5CS), and is spontaneously converted to pyrroline-5-carboxylate and subsequently reduced to proline by the enzyme pyrroline-5-carboxylate reductase (P5CR). The expression of the P5CS gene is controlled by a feedback mechanism, limiting the proline content in the cells (Zhang et al., 1995). The work of Zhang et al. (1995) generated a mutant P5CS from Vigna aconitifolia (VaP5CS-F129A) insensitive to gene expression control, but fully functional. This mutant gene was assembled with the constitutive cauliflower mosaic virus 35S (CaMV35S) promoter and used to transform Swingle citrumelo by Molinari (2003), whose transgenic plants were later evaluated by Campos et al. (2011). Those plants had superior performance under controlled drought conditions compared to non-transgenic Swingle; however, under severe stress condition the level of proline was equivalent in both genotypes, raising the hypothesis that there are additional regulations for controlling the accumulation of proline.

Therefore, the main objectives of this work were to evaluate plants of Swingle citrumelo (Citrus paradisi Macfad. cv. Duncan x Poncirus trifoliata L. Raf.) containing the transgene construction CaMV35S::VaP5CS-F129A, with high proline accumulation, under water deficit conditions to get inferences about the regulation of other genes in the proline biosynthesis pathway.

\section{MATERIAL AND METHODS}

\section{Citrus materials}

Transgenic plants of Swingle citrumelo (Citrus paradise Mac. cv. Duncan x Poncirus trifoliata L. Raf) used in this study were obtained by Molinari (2003). These plants were transformed by Agrobacterium tumefasciens and contain the gene VaP5CS-F129A under a constitutive promoter (CaMV 35S) and the selectable marker gene nptII under control of the NOS promoter (Zhang et al., 1995). Before the experiment, these plants were propagated by cuttings, maintained in 20-liter vases with commercial substrate based on pine bark and pruned to uniform their size. These plants are copies of the transformation event 20 and of a non-transformed control plant that was submitted to the same tissue culture conditions as the transgenics.

\section{Trial design}

The experiment was carried out in a greenhouse of the Laboratory of Biotechnology, located in the Instituto Agronômico do Paraná (IAPAR) in Londrina, PR, Brazil. For the experiment, twelve 5 year-old plants of Swingle citrumelo were distributed in six replicates containing the transgenic construction and six non-transgenic control plants arranged in completely randomized design. Plants were subjected to periods of drought stress by suspending irrigation. Leaf samples were collected up to 60 days without irrigation (d.w.i.) and were subjected to physiological, biochemical and molecular analyses. Two leaves in same stage of development were collected from each plant, immediately immersed in liquid $\mathrm{N}_{2}$ and transferred to a freezer at $-80{ }^{\circ} \mathrm{C}$ until further analysis. The treatments were named 'no stress' (NS) when the plants showed relative water content (RWC) above $90 \%$, 'moderate stress' (MS) within 90 and 79\% of RWC and 'severe stress' (SS) below 79\% of RWC. The RWC of the plants were measured every 3-4 days.

\section{Relative Water Content (RWC)}

RWC was based on the technique described by Slavik (1974). Leaf disks of the same diameter were collected at dawn from leaves with the same stage of development at the middle third of the plants. They were immediately weighted (FM, fresh mass) and soaked in water to reach its 
full turgor, when the disks were again weighted (TM, turgid mass). Next, the leaf discs dried in an oven at $60{ }^{\circ} \mathrm{C}$ to stabilize the weight (DM, dry mass). The RWC was calculated by the relationship of the difference between fresh and dry mass over the difference between turgid and dry mass, as follows: $\mathrm{RWC}=[(\mathrm{FM}-\mathrm{DM}) /(\mathrm{TM}-\mathrm{DM})]^{*} 100$.

\section{Net photosynthesis, stomatal conductance and transpiration}

Net photosynthesis, stomatal conductance and transpiration were obtained using LCpro-SD portable leaf gas exchange system (ADC BioScientific Ltd). Measures were made between 10:00 and 11:00 A.M. in leaves at the same stage of development from the middle third height of plant. The artificial light was adjusted to $800 \mu \mathrm{mol}$ of photons $\mathrm{m}^{-2} \mathrm{~s}^{-1}$. Photosynthesis was expressed in $\mu \mathrm{mol} \mathrm{CO} \mathrm{m}^{-2} \mathrm{~s}^{-1}$, transpiration in $\mathrm{mmol} \mathrm{H} 2 \mathrm{O} \mathrm{m}^{-2} \mathrm{~s}^{-1}$, and stomatal conductance in $\mathrm{mol} \mathrm{H}_{2} \mathrm{O} \mathrm{m}^{-2} \mathrm{~s}^{-1}$.

\section{Quantification of proline content}

Extraction and quantification of proline content was based on the technique described by Bates et al. (1973) with some modifications. Leaves in the same stage of development from the middle third of plant height were collected between 3:00 and 4:00 A.M. and stored in a freezer at $-80^{\circ} \mathrm{C}$ until the maceration, when $50 \mathrm{mg}$ of leaf tissue were ground in liquid $\mathrm{N}_{2}$ and homogenized in $6 \mathrm{~mL}$ of sulfosalicylic acid $3 \%(\mathrm{w} / \mathrm{v})$. After centrifugation (7500 rpm) for $10 \mathrm{~min}, 2 \mathrm{~mL}$ of extract were collected and added to $2 \mathrm{~mL}$ of ninhydrin acid solution $(1.25 \mathrm{~g}$ of ninhydrin; $30 \mathrm{~mL}$ glacial acetic acid; $20 \mathrm{~mL} 6 \mathrm{M}$ phosphoric acid) and $2 \mathrm{~mL}$ of glacial acetic acid in $15 \mathrm{~mL}$ tubes. The samples were incubated at $100^{\circ} \mathrm{C}$ for $1 \mathrm{~h}$ and then placed on ice. It was added $4 \mathrm{~mL}$ of toluene, followed by stirring for $20 \mathrm{~s}$ for a complete extraction of proline. The supernatant was read in spectrophotometer at $520 \mathrm{~nm}$ and the absorbance compared to the standard curve of proline (20 to $100 \mu \mathrm{g} \mathrm{mL}^{-1}$ ). The analyses were done in triplicate and the results expressed in micromol of proline per gram of fresh weight $\left(\mu \mathrm{mol} \mathrm{g} \mathrm{FM}^{-1}\right)$.

\section{Statistical analysis}

Proline content was assessed under three levels of water conditions (NS, MS and SS) and contrast of the means ( $\mathrm{Y}=$ Xtransgenic - Xnon-transgenic) was analyzed using the Scott-knott test $(\mathrm{p}<0.05)$. The variables RWC, net photosynthesis, stomatal conductance and transpiration were compared by regression analysis, since there was dependence between the variables and the period without irrigation.

\section{RNA sequencing and bioinformatics}

The analysis of RNA-Seq were carried out using leaves of non-transgenic and transgenic plants under similar relative water content, at moderate stress (MS) level. The biological replicates were formed by pools of leaves from non-transgenic and transgenic plants, with and without stress, collected in three consecutive days. Midribs of citrus leaves in same stage of development were cut, kept in a $-80{ }^{\circ} \mathrm{C}$ freezer until processing. Sample preparation and quality analysis for RNA-seq were carried out by the laboratory ParteCurae (2017) in São Carlos, SP and the RNA sequencing was done by the Central Laboratory of High Performance Technologies in Life Sciences - LaCTAD, at the Universidade Estadual de Campinas (Unicamp, 2017), Campinas SP. Sequences of cDNA (reads), were first processed using the software Fastqc (Bioinformatics, 2017). In order to eliminate possible mistakes of sequencing and contamination with adapters, the software Trimmomatic (Bolger et al., 2014) was used for data cleaning. The second step included mapping of the reads in the reference (annotated genes) and normalization of expression. At this stage, the program RSEM (Li \& Dewey, 2011) was used. As reference, we used the 33.930 genes from the database CITRUSGDB-Citrus partly Database (Citrusgenomedb, 2017), which was created by the international citrus consortium group, based on the genome sequencing of Clementine tangerine (Citrus clementina hort. ex Tanaka), sweet orange (Citrus sinensis L. Osbeck) and Poncirus trifoliata L. Raf. With that, 12 libraries were sequenced: NTI) Non-transgenic-Irrigated, libraries 1 to 3; NTNI) Non-transgenic-Not-Irrigated, libraries 4 to 6; TI) Transgenic-Irrigated, libraries 7 to 9; and TNI) Transgenic-Not-Irrigated, libraries 10 to 12. Each library was sequenced 4 times (Lanes 1-4), generating appropriate quality basis ( $\%$ base $>=\mathrm{Q} 30)$. The total sum of gross sequences exceeded 466 million, which were subsequently processed and used to assembly the contiguous sequences (contigs). After cleaning and processing, more than 151 million sequences had homology to known genes $(41.13 \%)$ and were mapped with a percentage of transcripts per million (TPM) of sequences, which was used as a measure of relative gene 
expression. Three replicates of them were transformed to $\log _{10}$ and averaged to generate the TPM mean value of relative expression for each selected transcript, whose putative functions were further confirmed by Blast-N and Blast-X analyses (BLAST, 2017).

\section{RESULTS AND DISCUSSION}

\section{Proline content}

Transgenic plants showed significantly higher proline content than the non-transgenic Swingle citrumelo in the first two evaluated periods of water deficit (no stress - NS and moderate stress - MS levels) (Figure 1). Under no stress (NS) the average value of the free proline content was 11.43 and $109.07 \mu \mathrm{mol} \mathrm{g} \mathrm{g}^{-1}$ of fresh leaf tissue in control and transgenic plants, respectively, showing a 9 -fold increase in free proline provided by the constitutive expression of the P5CS transgene in a normal situation of water supply. In conditions of moderate stress (MS), transgenic plants still produce 3.84 times more proline than the non-transgenic. Under severe stress (SS) non-transgenic plants of Swingle citrumelo showed a pronounced increase in free proline content, reaching $182.18 \mu \mathrm{mol} \mathrm{g}^{-1}$ of fresh leaf tissue, which is similar to the value detected in the transgenic plants $\left(186.92 \mu \mathrm{mol} \mathrm{g}^{-1}\right)$.

It was expected that transgenic plants with functional P5CS gene under control of the constitutive CaMV35S promoter indeed produce more proline than the non-transgenic

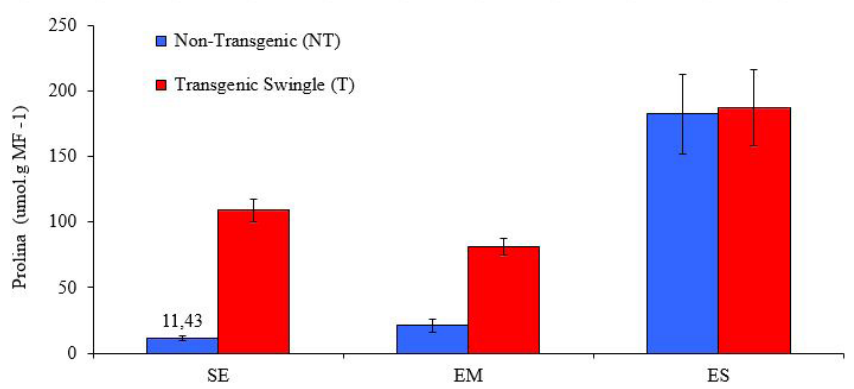

Figure 1. Content of endogenous free proline in leaves of non-transgenic (NT) and transgenic (T) plants of Swingle citrumelo containing the mutant gene VaP5CS-F129A, under control of the constitutive CaMV35S promoter in three conditions: no stress (NS), moderate stress (MS) and severe stress (SS). The values represent the means \pm standard errors. The comparison of means in each stress level was performed by Tukey test, at $5 \%$ of probability. plants, and this was observed in conditions without stress and with moderate stress. Only when plants reached severe stress (SS) condition the free proline accumulated at similar levels in both genotypes. Nevertheless, over the experimental period without irrigation, and more pronounced until reaching the severe stress (SS) condition, the non-transgenic plants were also able to accumulate high levels of proline, probably due to activation of their native proline biosynthetic pathway. On the other hand, in a previous report using this same construct, Campos et al. (2011) found equivalent free proline in transgenic Swingle citrumelo (around $130 \mu \mathrm{mol} \mathrm{g}^{-1}$ leaf tissues) under irrigated and water deficit conditions. This difference in absolutte values from our results could be caused by the stress levels, duration of the stress, physiological status and age of the plants used for the experiment.

Proline is known as an important adaptive response to abiotic stress, mainly due to its osmoprotective property (Ashraf \& Foolad, 2007), and is also present in other plant species subjected to stress conditions (Hoque et al., 2008). Molinari et al. (2004), working with transgenic plants of Carrizo citrange transformed with the same mutant VaP5CS-F129A gene and CaMV35S promoter, obtained proline accumulation values ( $120 \mu \mathrm{mol}$ to $240 \mu \mathrm{mol} \mathrm{g}^{-1}$ of leaf tissues after 20 days of water stress) similar to the ones found in this work. Therefore, this response represents a regulatory mechanism of water loss by reducing the water potential in the leaf cells by accumulating free proline in the cytoplasm.

Obviously, drought tolerance conferred by proline does not mean "immunity" against the effects of drought. But apparently plants with earlier and higher free proline accumulation have greater capacity of gradual adaptation to the increased stress caused by water deficit. Conditions of moderate drought stress is a common and important environmental factor in Brazil to cause osmotic stress and negative impact on plant growth and crop production. To restrain this kind of stress, plants normally reduce the osmotic potential of their cells through synthesis and accumulation of osmolyte agents such as glycines, polyamines and a variety of sugars and sugar alcohols (Valliyodan \& Nguyen, 2006; Oliveira et al., 2014). The transgenic plants studied here demonstrated that the ability accumulating the amino acid proline in excess up to the intermediate or moderate level of stress can be a way to forestall the deleterious effects of dry spells that often result in low productivity and crop failure. 


\section{General evaluation of plants}

Plants entered into drought stress in distinct periods after the suspension of irrigation. Up to 30 days without irrigation (d.w.i.), a better general appearance of transgenic plants was observed (Figure 2). Beyond that period, there was a gradual deterioration in several characteristics for all tested plants (transgenic and non-transgenic) until the end of the experiment (60 d.w.i.). This time period is similar to what normally occurs in field conditions during the dry season in most of the Brazilian citrus belt.

The visual assessments showed clearly that under extreme conditions of drought, beyond 40 d.w.i., all tested plants suffered similar debilitation. Even transgenic plants with higher capacity to accumulate proline earlier in time were not able to tolerate this condition of severe stress. In this condition, all Swingle citrumelo plants (transgenic and non-transgenic) showed twisting of leaves, absence of new blooming and much debilitated aspects at the end of the experiment. However, there was no loss of plants, since none was left to reach the permanent wilting point (PWP).

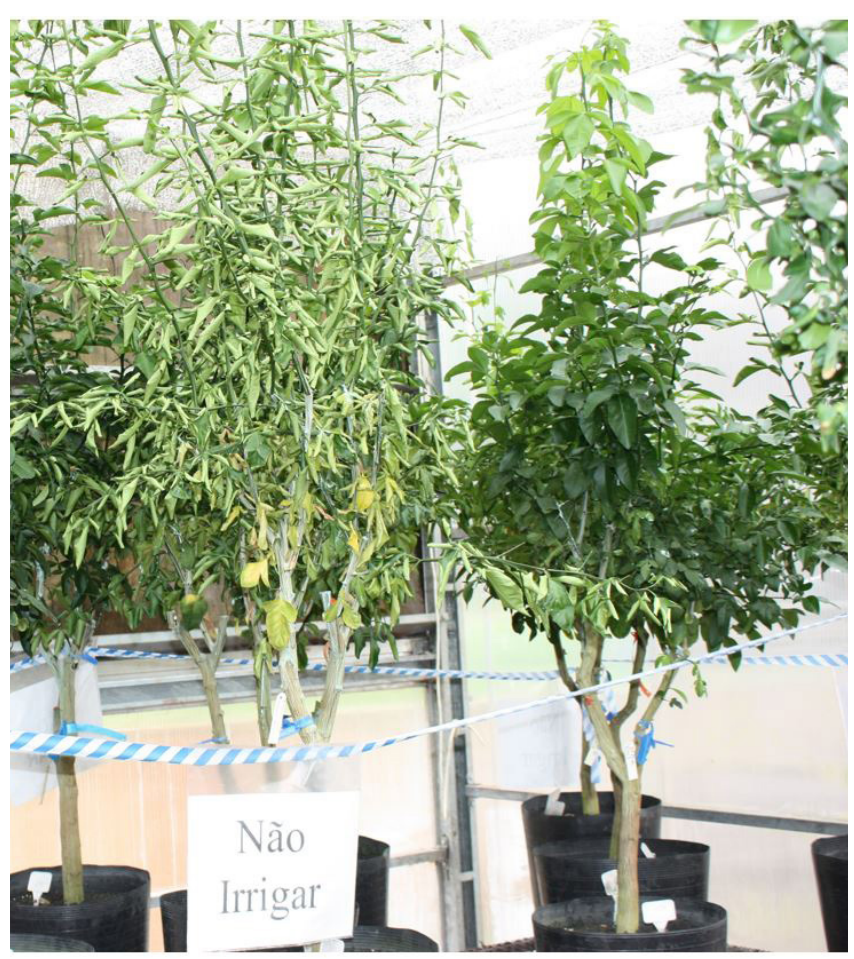

Figure 2. Visual differences after 30 days without irrigation (d.w.i.) between non-transgenic (plant number 3) and transgenic (plant number 11) Swingle citrumelo plants.
Considering that the major losses imposed to commercial orchards are due to shorter periods of drought in critical times, such as at flowering and fruit set periods, the tested transgenic Swingle citrumelo event could have a better performance in field conditions than non-transgenic plants.

\section{Relative Water Content (RWC)}

In normal conditions of water supply, non-transgenic and transgenic plants showed $95 \%$ of RWC but declined dramatically after 40 d.w.i. up to the end of the experiment (Figure 3A). But the progress of the decline was different between the two genotypes (Figure 3B). From the 26th to 34th d.w.i. the transgenic plants displayed significantly higher RWC than the non-transgenic controls. For example, on the 30th d.w.i., the transgenic plants still showed nearly

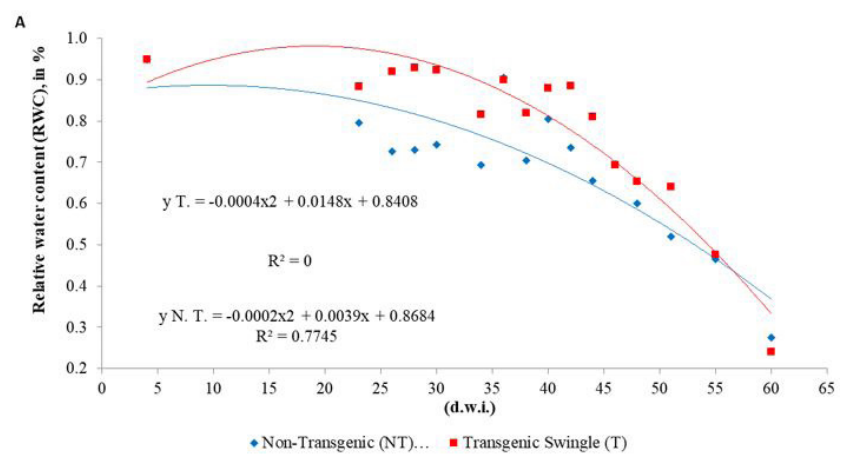

B



Figure 3. Relative water content (RWC) in transgenic plants (T) of Swingle citrumelo containing the VaP5CS-F129A mutant gene under the control of the constitutive CaMV35S promoter and non-transformed plants (N.T.): (A) regression analysis for the whole period of days without irrigation (d.w.i.); and (B) Contrast of means analyzed by Scott-knott test between the 26th and 34th d.w.i., where different letters represent a significant difference between them, with $\mathrm{p}<0.05$. (obs: between the 7th and 20th d.w.i. no data was recorded). 
$90 \%$ of RWC in the leaves compared to about $65 \%$ in the non-transgenics. This performance is important because even in the summer time any dry spells would affect the formation of juice sacs, impacting the industrial quality of the crop. Rootstock that is able to better overcome dry spells may be of practical use for citrus growers.

\section{Net photosynthesis}

The net photosynthetic rate observed in plants under water deficit declined throughout the period without irrigation (Figure 4). Between the 26th and 34th d.w.i. the net photosynthesis in transgenic was superior to non-transgenic plants but with no significant difference between the genotypes. It is worthy to note that at 30th d.w.i., control plants showed net photosynthetic rate

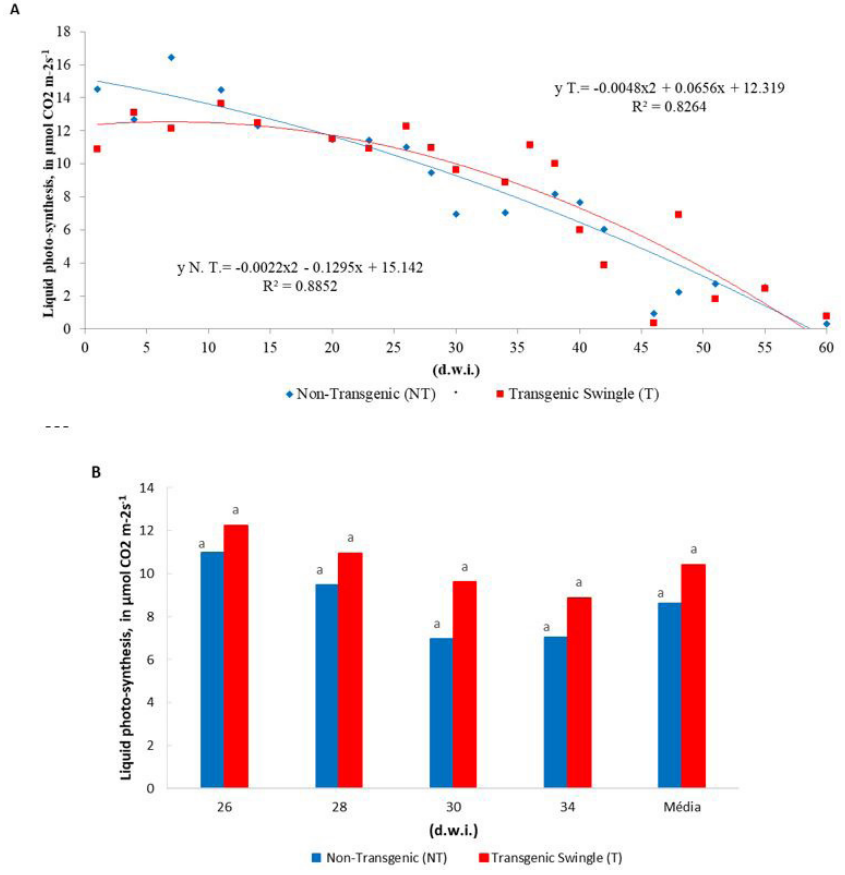

Figure 4. Net photosynthesis rates associated with drought stress in non-transgenic (NT) and transgenic (T) Swingle citrumelo plants containing the mutant gene VaP5CS-F129A, under control of the constitutive CaMV35S promoter. (A) Regression analysis showing the evolution of net photosynthesis after different periods without irrigation; and (B) Grouping of net photosynthesis by number of days without irrigation (d.w.i.); values represent the mean of the period; contrast of means analyzed by Scott-knott test between the 26th and 34th d.w.i., where same letters represent no significant difference between them, with $\mathrm{p}<0.05$. of $6.96 \mu \mathrm{mol} \mathrm{CO}_{2} \mathrm{~m}^{-2} \mathrm{~s}^{-1}$ while the transgenic plants had photosynthetic rate of $9.61 \mu \mathrm{mol} \mathrm{CO} \mathrm{m}^{-2}$. $\mathrm{s}^{-1}$. Probably because the high variability observed within the samples $(\mathrm{CV}=56.52 \%$, data not shown), it was not possible to detect significant differences. Campos et al. (2011) observed differences in net photosynthesis between transgenic and control plants up to 14 days of water deprivation using younger Swingle citrumelo plants, corroborating to the data obtained in this study which shows that the overall photosynthetic rate in transgenic plants is higher than in non-transformed controls up to intermediate levels of water deficit. After 40 d.w.i., both genotypes showed an accentuated fall in photosynthetic rate, condition that simulate what happen in field conditions when water deficit progresses toward severe levels of stress.

\section{Transpiration}

During the initial conditions of water deficit, the transpiration rates were similar in transgenic and non-transgenic plants, with values ranging from 3 to $4 \mathrm{mmol} \mathrm{H}_{2} \mathrm{O} \mathrm{m}^{-2} \mathrm{~s}^{-1}$ (Figure 5). From the fourteenth d.w.i. onward, there was a slightly fall of transpiration in non-transgenic plants. Meanwhile, the rate of transpiration of transgenic plants remained higher throughout the evaluated periods, but with no significant difference between them (Figure 5B). The regression analysis also showed this constant trend of greater transpiration in transgenic plants during the experimental time.

This result can be explained by the higher RWC in transgenic compared to non-transgenic plants. Turgid cells may maintain stomata opening, and consequently enhancing gas exchange and generating superior values of transpiration in transgenic plants.

\section{Stomatal conductance}

Similarly to the rate of transpiration, stomatal conductance at the initial stress condition was similar in both genotypes (Figure 6), with average values of approximately $0.27 \mathrm{~mol} \mathrm{~m}^{-2} \mathrm{~s}^{-1}$, but with a significant difference between the genotypes on 34th d.w.i. (Figure 6B). The regression analysis also showed this general trend of higher stomatal conductance in transgenic plants toward the end of the period without irrigation. The stomatal conductance is influenced by factors such as light intensity, vapor pressure deficit, and amount of water in the leaves (Landsberg \& Gower, 1997). The higher stomatal conductance in the 


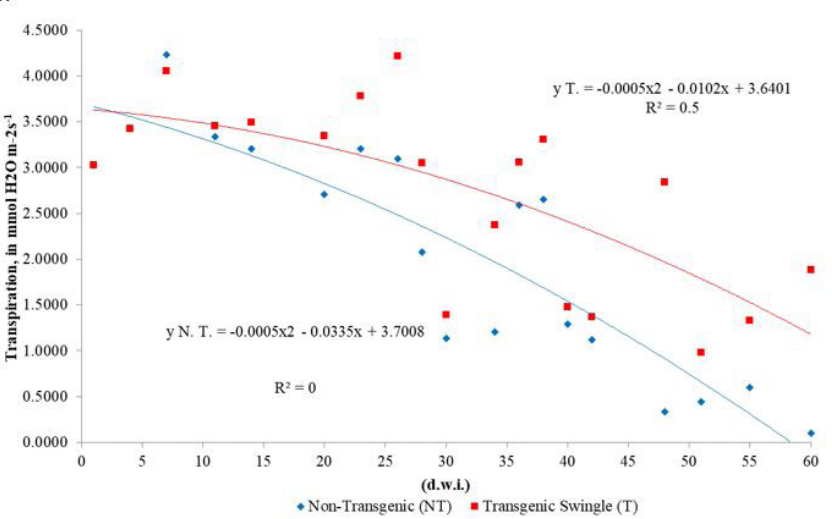

$-$

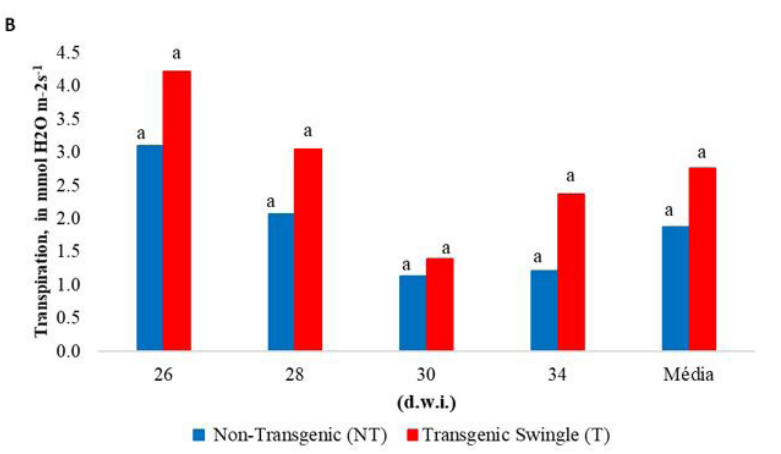

Figure 5. Transpiration associated with drought stress of non-transgenic (NT) and transgenic (T) Swingle citrumelo plants containing the mutant gene VaP5CS-F129A, under control of the constitutive CaMV35S promoter. (A) Regression analysis showing the evolution of transpiration after different periods of water deficit; and (B) Grouping of transpiration by number of days without irrigation (d.w.i.); values represent the mean of the period; contrast of means analyzed by Scott-knott test between the 26th and 34th d.w.i., where same letters represent no significant difference between them, with $\mathrm{p}<0.05$.

transgenic event is compatible with the superior RWC observed in these plants, especially in the period between the 26th and 34th. d.w.i.

\section{Expression of proline metabolism genes}

From the large amount of data obtained from the RNA-seq, four transcripts were chosen that matched two genes in the proline metabolism pathway: the $\Delta$-pyrroline-5-carboxylate reductase (P5CR) and the proline dehydrogenase (ProDH), respectively acting in synthesis and catabolism of proline (Figure 7).


Figure 6. Stomatal conductance associated with drought stress of non-transgenic (NT) and transgenic (T) Swingle citrumelo plants containing the mutant gene VaP5CS-F129A, under control of the constitutive CaMV35S promoter. (A) Regression analysis showing the evolution of stomatal conductance after different periods of water deficit; and (B) Grouping of stomatal conductance by number of days without irrigation (d.w.i.); values represent the mean of the period; contrast of means analyzed by Scott-knott test between the 26th and 34th d.w.i., where different letters represent a significant difference between them, with $\mathrm{p}<0.05$.

The transcripts Ciclev10005607 and Ciclev10005964 were assigned as putative isoforms of $\Delta$-pyrroline-5-carboxylate reductase (P5CR) gene. However, the expression profiling of these isoforms was not similar between the analyzed water deficit treatments (Figure 8A). For Ciclev10005607, the amount of mRNAs encoding P5CR was similar between both non-transgenic treatments, irrigated and not irrigated (NTI and NTNI), and transgenic with irrigation (TI), which in turn were significantly superior to the expression in the transgenic plants with no irrigation (TNI). The expression of Ciclev10005964 was detected only in non-transgenic plants with irrigation (NTI). In this condition, probably the high content of free proline accumulated in cells due 
to the water deficit stress (NTNI) and constitutive proline accumulation (TNI and TI) has negatively regulated the expression of the P5CR gene. For both transcripts, there were differences comparing the two extreme situtations, where the non-transgenic irrigated (NTI) and transgenic not irrigated (TNI) plants had respectivelly not altered and significantly reduced expression of P5CR. Probably the low stimulus for proline accumulation of having no constitutive transgene and no water stress (NTI) did not impact the expression of $\mathrm{P} 5 \mathrm{CR}$, while the high stimulus

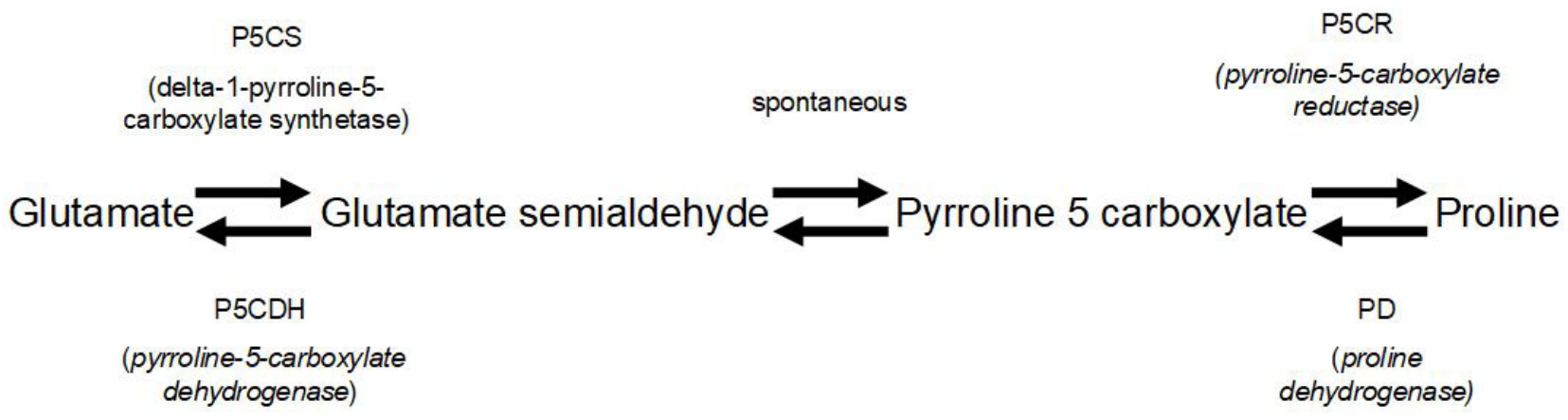

Figure 7. Proline biosynthesis from glutamate and degradation pathway. Adapted from: Verbruggen \& Hermans (2008).

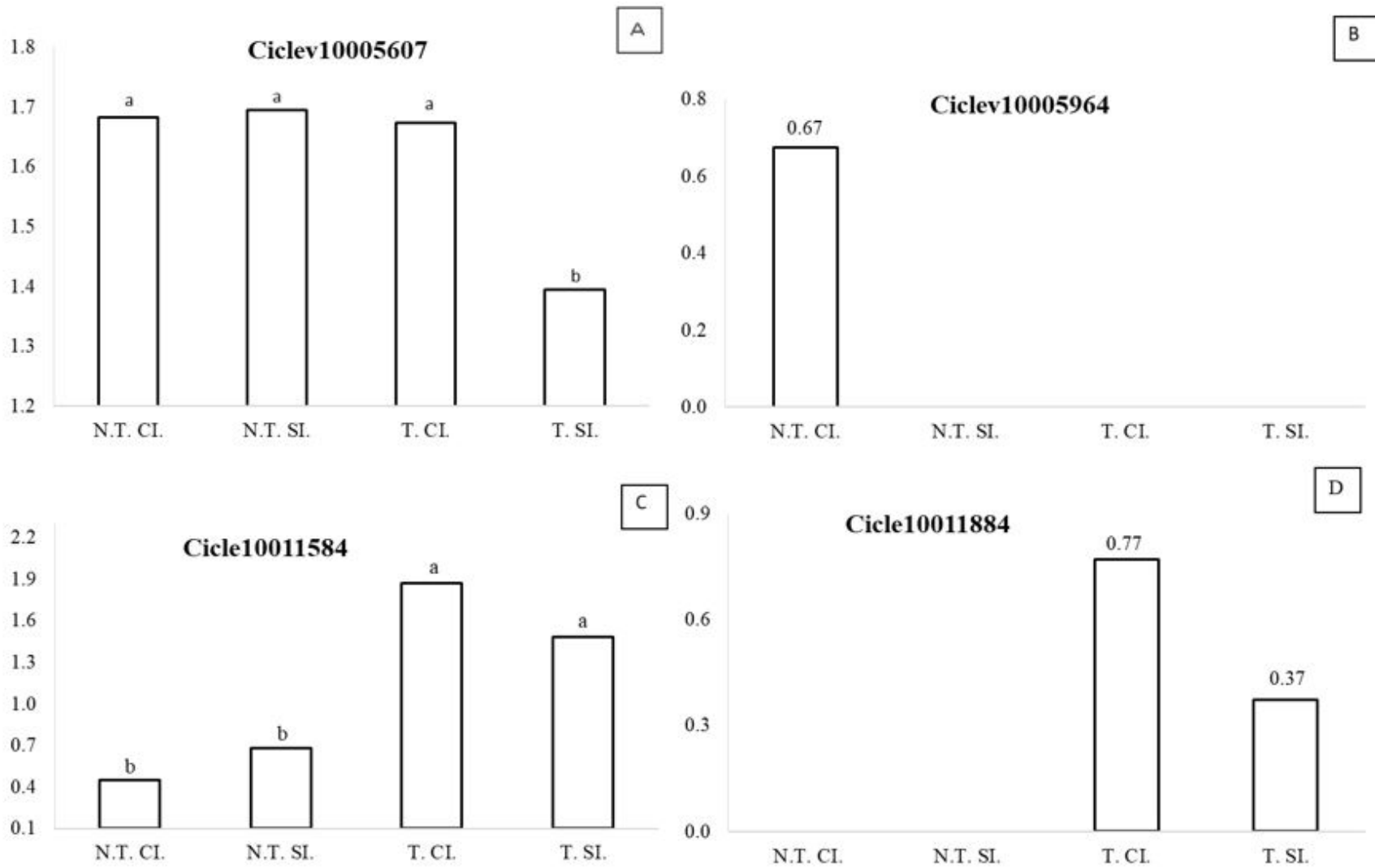

Figure 8. Expression profile of putative isoforms of $\Delta$-pyrroline-5-carboxylate reductase (P5CR) and proline dehydrogenase (ProDH) genes, assessing respectivelly the transcripts (A) Ciclev10005607, (B) Ciclev10005964, (C) Ciclev10011584 and (D) Ciclev10011884 under different genotypes and water deficit treatments: non-transgenic irrigated (NTI), non-transgenic not irrigated (NTNI), transgenic irrigated (TI) and transgenic not irrigated (TNI). Relative expression represents the transcripts per million (TPM) of sequences transformed to Log 10 and averaged to generate the values displayed on axis y. Contrast of means analyzed by Tukey test, where different letters represent a significant difference with $\mathrm{p}<0.05$. 
for proline accumulation of having constitutive transgene and water stress (TNI) decreased the expression of P5CR.

The two other transcripts analyzed (Figure 8B) were related to proline dehydrogenase (ProDH) gene (Ciclev10011584 and Ciclev10011884). The expression profiling for these transcripts were not similar between the genotypes tested, showing higher expression in transgenic treatments (TI and TNI) compared to non-transgenics (NTI and NTNI), regardless the water status of the plants. The ProDH enzyme is certainly needed to recycle the large amounts of free proline in the studied transgenic plants, which therefore, increased expression of the endogenous ProDH gene.

The enzyme P5CR was identified and characterized in several other species of plants. Delauney \& Verma (1990) observed the increased expression of the P5CR gene in cDNA libraries of soybean nodules, when the plant was subjected to osmotic stress. Subsequently, Szoke et al. (1992) super-expressed the soybean P5CR gene in tobacco, which did not show significant increase of proline levels in transgenic plants, even with 100 times greater expression of the P5CR gene than in non-transgenic plants. Thus, P5CR was not considered a limiting factor to proline accumulation in plants. In this work, we found evidence that large amounts of free proline caused by the insertion of the P5CS transgene down-regulates the expression of the P5CR gene in plants under not irrigated conditions.

Both P5CR and ProDH genes were probably modulated to control the proline biosynthesis and degradation mechanisms. Reducing the expression of P5CR and raising the expression of ProDH would minimize over accumulation of proline helping to avoid scavenge for carbon and nitrogen to other metabolic pathways, which are also important for development and productivity of plants.

Therefore, a better understanding of the altered expression of these two genes of the proline biosynthesis pathway from glutamate opens new opportunities to study rootstocks able to tolerate drought stress based also on P5CR and ProDH genes. The data generated in this work, especially in bioinformatics, will also be useful for future analyses of other genes and metabolic pathways involved in the response to drought stress.

\section{ACKNOWLEDGEMENTS}

Authors are thankful to Suely Ario Kudo, Lucinéia Maria da Silva and Carlos Henrique da Silva Gonçalves, lab and field technicians of LBI-IAPAR for their dedication to the success of this work; to Carmen Fontes for english reviewing; to CAPES (Coordenação de Aperfeiçoamento de Pessoal de Nível Superior) for granting the scholarship to Diliane Barichello; and to the graduation program at IAPAR.

\section{REFERENCES}

Adams E \& Frank L (1980) Metabolism of proline and the hydroxyprolines. Annual Review of Biochemistry 49(1): 1005-1061. PMid:6250440. http://dx.doi.org/10.1146/ annurev.bi.49.070180.005041.

Albrigo LG \& Saúco VG (2004) Flower bud induction, flowering and fruit-set of some tropical and subtropical fruit tree crops with special reference to citrus. Acta Horticulturae 632(10): 81-90. http://dx.doi.org/10.17660/ ActaHortic.2004.632.10.

Arruda IM, Moda-Cirino V, Buratto JS \& Ferreira JM (2015) Crescimento e produtividade de cultivares e linhagens de amendoim submetidas a déficit hídrico. Pesquisa Agropecuária Tropical 45(2): 146-154. http:// dx.doi.org/10.1590/1983-40632015v4529652.

Ashraf M \& Foolad MR (2007) Improving plant abiotic-stress resistance by exogenous application of osmoprotectants glycinebetaine and proline. Environmental and Experimental Botany 59(2): 206-216. http://dx.doi. org/10.1016/j.envexpbot.2005.12.006.

Bates LS, Waldren RP \& Teare ID (1973) Rapid determination of free proline for water stress studies. Plant and Soil 39(1): 205-207. http://dx.doi.org/10.1007/BF00018060.

Bioinformatics - Babraham Bioinformatics (2017). Available from: $<\mathrm{http}: / /$ www.bioinformatics.babraham. ac.uk/projects/fastqc $>$. Accessed: 9 Mar. 2017.

BLAST - Basic Local Alignment Search Tool (2017). Available from: $<$ https://blast.ncbi.nlm.nih.gov $>$. Accessed: 9 Mar. 2017.

Bolger AM, Lohse M \& Usadel B (2014) Trimmomatic: a flexible trimmer for Illumina Sequence Data. Bioinformatics 30(15): 2114-2120. PMid:24695404. http://dx.doi. org/10.1093/bioinformatics/btu170.

Bürling K, Cerovic ZG, Cornic G, Ducruet J-M, Noga G \& Hunsche M (2013) Fluorescence-based sensing of drought-induced stress in the vegetative phase of four contrasting wheat genotypes. Environmental and 
Experimental Botany 89: 51-59. http://dx.doi.org/10.1016/j. envexpbot.2013.01.003.

Campos MKF, Carvalho K, Souza FS, Marur CJ, Pereira LFP, Bespalhok Filho JC \& Vieira LGE (2011) Drought tolerance and antioxidant enzymatic activity in transgenic 'Swingle' citrumelo plants over-accumulating proline. Environmental and Experimental Botany 72(2): 242250. http://dx.doi.org/10.1016/j.envexpbot.2011.03.009.

Carlos EF, Stuchi ES \& Donadio LC (1997) Porta-enxertos para a citricultura paulista. Jaboticabal: FUNEP/UNESP. $47 \mathrm{p}$.

Carneiro MMLC (2011) Trocas gasosas e metabolismo antioxidativo em plantas de girassol em resposta ao déficit hídrico. Master Dissertation, Universidade Federal de Pelotas, Pelotas.

Chaves Filho JT \& Stacciarini-Seraphin ES (2001) Alteração no potencial osmótico e teor de carboidratos solúveis em plantas jovens de lobeira (Solanum lycocarpum St.-Hil.) em resposta ao estresse hídrico. Brazilian Journal of Botany 24(2): 199-204. http://dx.doi.org/10.1590/ S0100-84042001000200010.

Citrusgenomedb - Citrus Genome Database (2017). Available from: <http://www.citrusgenomedb.org>. Accessed: 9 Mar. 2017.

Delauney AJ \& Verma DPS (1990) A soybean gene encoding pyrroline-5-carboxylate reductase was isolated by functional complementation in Escherichia coli and is found to be osmoregulated. Molecular \& General Genetics 221(3): 299-305. PMid:2199815. http://dx.doi. org/10.1007/BF00259392.

Delauney AJ, Hu CA, Kishor PBK \& Verna DPS (1993) Cloning of ornithine -aminotransferase cDNA by transcomplementation in Escherichia coli and regulation of proline biosynthesis. The Journal of Biological Chemistry 268: 18673-18678. PMid:8103048.

Hare PD \& Cress WA (1997) Metabolic implications of stress-induced proline accumulation in plants. Plant Growth Regulation 21(2): 79-102. http://dx.doi. org/10.1023/A:1005703923347.

Hoque MA, Banu MN, Nakamura Y, Shimoishi Y \& Murata Y (2008) Proline and glycinebetaine enhance antioxidant defense and methylglyoxal detoxi fi cation systems and reduce NaClinduced damage in cultured tobacco cells. Journal of Plant Physiology 165(8):
813-824. PMid:17920727. http://dx.doi.org/10.1016/j. jplph.2007.07.013.

Kramer PJ \& Boyer JS (1995) Water relations of plants. San Diego: Academic Press. 489 p.

Landsberg JJ \& Gower ST (1997) Applications of physiological ecology to forest management. San Diego: Academic Press. 344 p.

Li B \& Dewey CN (2011) RSEM: accurate transcript quantification from RNA-Seq data with or without a reference genome. BMC Bioinformatics 12(323): 1-16. PMid:21816040.

Molinari HBC (2003). Transformacão genética de portaenxertos para Citrus spp. visando obter maior tolerância ao estresse hídrico. Master Dissertation, Universidade Estadual de Londrina, Londrina.

Molinari HBC, Marur CJ, Bespalhok Filho JC, Kobayashi AK, Peleggi M, Leite Júnior RP, Pereira LFP \& Viera LGE (2004) Osmotic adjustment in transgenic citrus rootstock Carrizo citrange (Citrus sinensis Osb. $\mathrm{x}$ Poncirus trifoliata L. Raf.) overproducing proline. Plant Science 167(6): 1375-1381. http://dx.doi.org/10.1016/j. plantsci.2004.07.007.

Oliveira CS, Carlos EF, Vieira LGE, Lião LM \& Alcantara GB (2014) HR-MAS NMR metabolomics of 'Swingle' citrumelo rootstock genetically modified to overproduce proline. Magnetic Resonance in Chemistry 52(8): 422429. PMid:24842075. http://dx.doi.org/10.1002/mrc.4082.

ParteCurae (2017). Available from: $<$ http://www.partecurae. com.br/index.html>. Accessed: 9 Mar. 2017.

Pereira JWL, Melo Filho PA, Albuquerque MB, Nogueira RJMC \& Santos RC (2012) Mudanças bioquímicas em genótipos de amendoim submetidos a déficit hídrico moderado. Ciência Agronômica 43(4): 766-773. http:// dx.doi.org/10.1590/S1806-66902012000400019.

Pimentel C (2004) A relação da planta com a água. Seropédica: EDUR. 190 p.

Pompeu Junior J \& Blumer S (2008) Laranjeiras e seus porta-enxertos nos viveiros de mudas cítricas do Estado de São Paulo. Laranja 29(1-2): 35-50.

Sentelhas PC (2005) Agrometeorologia dos citros. In: Mattos Junior D, De Negri JD, Pio RM \& Pompeu Junior J (Eds). Citros. Campinas: Instituto Agronômico e Fundag, p. 569. 
Slavik B (1974) Methods of studing plant water relations. Prague: Academy of Science. 449 p.

Špoljarević M, Agić D, Lisjak M, Gumze A, Wilson ID, Hancock JT \& Teklić T (2011) The relationship of proline content and metabolism on the roductivity of maize plants. Plant Signaling \& Behavior 6(2): 251-257. PMid:21415600. http://dx.doi.org/10.4161/ psb.6.2.14336.

Szoke A, Miao GH, Hong ZL \& Verma DPS (1992) Subcellular location of $\Delta 1$-pyrroline-5-carboxylate reductase in root nodule and leaf of soybean. Plant Physiology 99(4): 1642-1649. PMid:16669085. http:// dx.doi.org/10.1104/pp.99.4.1642.

Turkan I (2011) Plant responses to drought and salinity stress: developments in post-genomic Era. In: Turkan I (Ed). Advances in botanical research. London: Elsevier, p. 592.

Unicamp - Universidade Estadual de Campinas (2017). Available from: $<$ http://www.lactad.unicamp.br $>$. Accessed: 9 Mar. 2017.
Valliyodan B \& Nguyen HT (2006) Understanding regulatory networks and engineering for enhanced drought tolerance in plants. Current Opinion in Plant Biology 9(2): 189-195. PMid:16483835. http://dx.doi. org/10.1016/j.pbi.2006.01.019.

Verbruggen N \& Hermans C (2008) Proline accumulation in plants: a review. Amino Acids 35(4): 753-759. PMid:18379856. http://dx.doi.org/10.1007/ s00726-008-0061-6.

Zhang CS, Lu Q \& Verma DPS (1995) Removal of feedback inhibition of delta-1-pyrroline-5-carboxylate synthetase, a bifunctional enzyme catalyzing the first 2 steps of proline biosynthesis in plants. The Journal of Biological Chemistry 270(35): 20491-20496. PMid:7657626. http://dx.doi.org/10.1074/jbc.270.35.20491.

Received: March 09, 2017 Accepted: August 04, 2017 